\title{
Struktur modal dan keberlangsungan lembaga keuangan mikro
}

\author{
Indayani ${ }^{1}$, Imam Ghozali ${ }^{2}$ \\ ${ }^{1}$ Fakultas Ekonomi dan Bisnis, Universitas Syiah Kuala, Banda Aceh, Indonesia \\ ${ }^{2}$ Fakultas Ekonomi dan Bisnis, Universitas Diponegoro, Semarang, Indonesia \\ e-mail:1inya74@gmail.com; ${ }^{2}$ ghozali_imam@yahoo.com
}

\section{A R T I K E L I N F O}

Article history:

Available online

Keywords:

capital structure, sustainability, microfinance

\section{A B S T R A C T}

This study purpose to test the theory of capital structure (grants, equity, profits, savings, deposits, lingkage, subordinated loans and quasy capital) and its effect on sustainability in microfinance, particularly regulated institutions. The investigation involved a panel of 322 samples of conventional banks (BPR) throughout Indonesia for the period 2012-2014. The sampling method was based on proportional samples in the provinces/ districts. This research uses SEM analysis tool with WarpPLS to test hypothesis. Methods of data analysis were done by evaluating the measurement model and structural model. The results showed the equity, profit, savings and lingkage affected sustainability in microfinance. Meanwhile, grants, deposits, subordinated loans and quasy had no effect on the sustainability of microfinance. The implications of the policy show that savings and lingkage can be maintained and enhanced because they have an impact on improving the sustainability of the BPR. This research can be a reference for developing research related to the capital structure of microfinance in the future.

\begin{abstract}
A B S T R A K
Penelitian ini bertujuan menguji teori struktur modal (hibah, ekuitas, laba, tabungan, deposito, pinjaman lingkage, pinjaman subordinasi dan modal pinjaman/quasi) dan pengaruhnya pada keberlangsungan di lembaga keuangan mikro khususnya lembaga teregulasi. Investigasi melibatkan panel data dari 322 sampel bank konvensional (BPR) di seluruh Indonesia untuk periode 2012-2014. Metode pengambilan sampel ditetapkan berdasarkan sampel proporsional di propinsi dan kabupaten. Penelitian ini menggunakan alat analisis Structural Equation Modeling (SEM) dengan program WarpPLS untuk menguji hipotesis. Metode analisis data di lakukan dengan mengevaluasi model pengukuran dan model struktural. Hasil menunjukkan ekuitas, laba, tabungan dan pinjaman lingkage berpengaruh pada keberlangsungan keuangan mikro. Sementara itu, hibah, deposito, pimjaman subordinasi dan pinjaman quasi tidak berpengaruh pada keberlangsungan keuangan mikro. Implikasi pada kebijakan menunjukkan tabungan dan pinjaman lingkage dapat dipertahankan dan ditingkatkan karena berdampak meningkatkan keberlangsungan BPR. Penelitian ini dapat menjadi acuan untuk mengembangkan penelitian terkait struktur modal keuangan mikro di masa mendatang.
\end{abstract}

\section{Pendahuluan}

Tidak diragukan lagi bahwa keuangan mikro telah bekerja membantu masyarakat marginal di dunia dengan memberikan akses sumber keuangan yang sebagian besar diabaikan oleh bank umum dan lembaga pinjaman lainnya karena alasan skala ekonomi yang dianggap tidak cukup menguntungkan (Helms 2006; Guntz 2011; Robinson 2001), sehinngga lembaga keuangan mikro (LKM) mempunyai keunikan sendiri dibandingkan dengan perbankan umum karena berorientasi pada skala ekonomi kecil, profit-driven dan kesejahteraan masyarakat (de Aghion dan Morduch 2005; Hulme dan Mosley 1966; Paxton dan Fruman 1997; Torre dan Vento 2006; Otero dan Rhyne 1994; Robinson 2001; Ledgerwood 2008).

Menurut Morduch (2000), pendekatan institutional keuangan mikro, menekankan pada pentingnya keberlangsungan keuangan dan memberikan dampak positif pada nasabah. Pendekatan ini telah menggeser LKM bertransfomasi menjadi lembaga keuangan formal yang mandiri, independen dan beroperasi sebagai lembaga profit untuk meningkatkan pertumbuhan dan keberlangsungan (Charitonenko dan Afwan 2003; Christen dan Drake 
2002; Christen 2001; Hoque et al. 2011) dan mengarahkan lembaga keuangan mikro untuk memanfaatkan dana berbasis pasar (Frank 2008; Guntz 2011) yang menyebabkan transformasi struktur modal menjadi komplek.

Selain itu, keterbatasan modal (Bogan 2012), telah mencegah LKM dari memenuhi permintaan yang sangat besar dan tidak elastis (Dehejia et al. 2012) mengharuskan lembaga melakukan ekspansi pada sumber dana. Kurangnya akses terhadap modal menyebabkan pertumbuhan lebih lambat dan defisit operasional. Namun demikian, Akses dana pasar tidak hanya mengubah komposisi stuktur modal dan menambah cost of fund tetapi juga menimbulkan resiko likuiditas yang mengganggu keberlangsungan jika tidak dikelola dengan baik. Dengan demikian, transformasi struktur modal sebagai arus modal telah menjadi isu yang jauh lebih penting untuk pencapaian keberlangsungan keuangan.

Transformasi menuntut LKM formal tidak bisa tanpa akuisisi hutang dan tidak dapat beroperasi tanpa mobilisasi dana yang lebih besar dan terus menerus dari berbagai kategori deposito, tabungan dan giro (Uremadu 2012) dan hidup di dana pinjaman utang jangka pendek dan panjang di dalam bisnisnya. Transformasi memberi LKM pada diversifikasi pendanaan yang lebih luas, dan membuatnya lebih kompleks untuk keputusan struktur modal. Oleh karena itu, transformasi struktur modal menuntut LKM mengelola modal secara lebih baik untuk mencapai keberlangsungan keuangan.

Pengelolaan struktur modal identik dengan darimana sumber-sumber pendanaan perusahaan diperoleh dan bagaimana pendanaan ini dikelola dan merupakan kombinasi dari ekuitas dan hutang yang diperoleh oleh perusahaan (Meyer 2001; Besley dan Brigham 2008). Pengambilan keputusan struktur modal yang lebih baik akan meminimalkan risiko LKM, memaksimalkan fleksibilitas keuangan, dan mendorong solvabilitas jangka panjang yang diperlukan untuk menyediakan layanan keuangan yang berkelanjutan untuk masyarakat miskin. Keputusan struktur modal penting karena mempengaruhi laba bersih, sisi positif dan negatif dari keputusan ini memainkan peran penting dalam menentukan masa depan setiap bisnis untuk mencapai keberlangsungannya.

Pada literatur akademis, Modigliani dan Miller (1958) telah meletakkan dasar pemikiran keputusan struktur modal dengan nilai perusahaan yang dikenal dengan "capital structure irrelevance" di pasar sempurna. Asumsi proposisi-nya bahwa tingkat utang tidak berhubungan dengan aliran kas perusahaan. Bagaimanapun, kondisi menunjukkan bahwa kesimpulan ini tidak berlaku di pasar yang tidak sempurna, sehingga studi oleh Jensen dan Meckling (1976), Myers (1977), Williams (1987), Harris dan Raviv (1990), Grossman dan Hart (1982), Jensen (1986) telah mematahkan proposisi ini. Jensen dan Meckling (1976) berargumen bahwa perusahaan yang di danai oleh hutang cenderung untuk terlibat dalam strategi pergeseran resiko ketika mereka memiliki arus kas bebas yang tersedia.

Studi tentang struktur modal terhadap nilai perusahaan sangat maju saat ini baik pada kasus negara besar dan berkembang pada beragam industri dan perusahaan, misalnya sektor perbankan (Berger dan Di Patti 2006; Margaritis dan Psillaki 2007; Uremadu 2012), perusahaan listed (Salim dan Yadav 2012; Bertomeu et al. 2011; Umar et al. 2012; Abor 2005), perusahaan kecil (Cassar dan Holmes 2003), perusahaan konstruksi (Hung et al. 2002), manufaktur (Titman dan Wessels 1988; Umar et al. 2012), perusahaan non-profit (Lynch 2003), pertanian (Wu et al. 2014) dan sektor lainnya. Berbagai penelitian di industri dan sektoral tersebut telah berkembang lama dan meyumbangkan beragam hasil dan kesimpulan. Namun demikian, studi di area ini baru berkembang di industri keuangan mikro seiring dengan perkembangan industri ini di dunia.

Telah ada beberapa penelitian struktur modal dikeuangan mikro diantaranya Kyereboah-Coleman (2007b), menguji dampak struktur modal terhadap kinerja jangkuan di Ghana. Hoque et al. (2011) menguji dampak komersialisasi terhadap struktur modal, misi dan kinerja lembaga keuangan mikro (LKM) dan Bogan (2012), mengeksplorasi bagaimana perubahan struktur modal dapat meningkatkan efisiensi LKM dan kecukupan operasional.

Bagaimanapun, masalah struktur modal di keuangan mikro masih tetap kontroversial dan teka-teki. Studi sebelumnya berasal dari kasus gabungan beberapa negara seperti Asia Timur, Eropa Timur, Amerika Latin, Timur Tengah, dan Asia Selatan, dan kasus negara Ghana dan Uganda. Studi ini mengambil kasus wilayah Asia Tenggara khususnya Indonesia. Indonesia memiliki sejarah panjang pada munculnya revolusi keuangan mikro dan merupakan negara pertama yang mengembangkan keuangan mikro komersial di Asia. Sejak akhir abad 19 dengan berdirinya Bank Kredit Rakyat (BKR) dan Lumbung Desa yang menyediakan sebagian besar layanan keuangan mikro yang tersebar di 13.000 kepulauan. Pada tahun 1930, dengan peraturan Afdeelingsbank (AB) bertransformasi menjadi Bank Perkreditan Rakyat (BPR) yang merupakan cikal bakal berdirinya keuangan mikro formal di Indonesia (Robinson 2002). PAKTO 1988 memberikan kemudahan pendirian BPR dengan mengizinkan lembaga non formal untuk bertransformasi menjadi lembaga formal.

Tujuan dari penelitian ini adalah untuk menyelidiki efek langsung struktur modal dan keberlangsungan keuangan. Peraturan Afdeelingsbank, PAKTO 1980, UU no 7/1992, UU no 10/1998 dan UU No.1/2013 berimplikasi pada transformasi struktur modal LKM teregulasi dan dicirikan oleh ekuitas yang kecil, kepemilikan tersebar dan kedekatan pemilik tinggi. Berdasarkan teori agensi, penelitian ini mencoba menjelaskan prilaku berbagai individu yang mengintervensi struktur modal di keuangan mikro dan bagaimana pilihan struktur modal dapat mengurangi biaya agensi. Penelitian ini memberikan kontribusi pada literatur keuangan mikro tentang 
hubungan antara struktur modal dan keberlangsungan, dan memiliki implikasi kebijakan praktisi terutama pada industri keuangan mikro teregulasi.

Selanjutnya makalah ini disusun sebagai berikut, bagian kedua terkait dengan teori, literatur review dan hipotesis; bagian tiga metodologi penelitian; bagian empat hasil empiris dan diskusi; dan terakhir kesimpulan, keterbatasan, implikasi, rekomendasi dan agenda penelitian mendatang.

\section{Tinjauan Pustaka dan Perumusan Hipotesis}

\section{Trade off-Theory}

Konsep trade off dalam balancing theory adalah menyeimbangkan manfaat dan biaya dari penggunaan utang dalam struktur modal sehingga disebut pula sebagai trade off theory (Brigham et al. 1999). Berdasarkan teori Modigliani dan Miller (1958), semakin besar hutang yang digunakan, semakin tinggi nilai perusahaan. Namun demikian, model Modigliani dan Miller (1958) ini mengabaikan faktor biaya kebangkrutan dan biaya keagenan. Pada kenyatannya jarang ada perusahaan yang menggunakan dana sepenuhnya dari hutang karena biasanya perusahaan membatasi penggunaan hutang untuk menekan biaya-biaya yang berkaitan dengan kebangkrutan. Dengan demikian, Struktur modal terbaik hanya dapat ditemukan dengan menyeimbangkan antara keuntungan penggunaan hutang dengan biaya kebangkrutan dan biaya agensi yang disebut model trade off (Myers 1984).

Pada agency cost trade-off model manajer harus mempertimbangkan kepentingan pemilik dan juga kepentingan pemegang hutang. Secara khusus, manajer mendukung investasi berisiko yang menguntungkan pemegang saham dalam hal keberhasilan, namun demikian akan membebani kerugian pemegang obligasi dalam kasus kegagalan (Jensen dan Meckling 1976). Investor obligasi rasional menyadari jenis masalah overinvestment, dan karenanya mereka menuntut premi risiko dan akibatnya pembayaran bunga yang lebih tinggi sebagai kompensasi atas perilaku ini. Baik overinvestment dan kurangnya investasi adalah moral hazard manajerial, dan mereka cenderung menjadi lebih banyak untuk perusahaan yang sangat leverage yang menderita kesulitan keuangan. Namun demikian, hutang dapat memiliki dampak moderat pada konflik keagenan.

Hipotesis arus kas bebas Jensen (1986) berpendapat bahwa hutang memberikan efek mendisiplinkan, karena manajer dipaksa untuk menghasilkan arus kas yang konstan untuk memenuhi pembayaran utang perusahaan mereka. Berbeda dengan pembayaran dividen atau pembelian kembali saham, pembayaran bunga berkomitmen mewakili sinyal kredibel ke pasar bahwa perusahaan menikmati prospek yang menguntungkan. Oleh karena itu, dalam rangka untuk sampai pada keputusan pembiayaan yang optimal, manajer perlu mengevaluasi biaya agensi hutang (pergeseran risiko dan kurangnya investasi) terhadap biaya agensi ekuitas (masalah aliran kas bebas).

\section{Teori Agensi}

Teori agensi secara luas sudah digunakan pada penelitian struktur modal di literatur keuangan dan perbankan. Jensen dan Meckling (1976) yang meletakkan dasar teori agensi pada struktur modal, dan dilanjutkan oleh penelitian lainnya seperti (Harris dan Raviv 1990; Berger dan Di Patti 2006). Namun, bukti empiris tentang masalah ini masih bercampur dalam literatur yang ada, di mana hanya bank umum, UKM atau perusahaan besar dan terdaftar. Pada literatur keuangan mikro dimana asimetri informasi tinggi, kajian teori agensi di struktur modal masih diperlukan, Oleh karenanya sangat signifikan mengangkat teori agensi dalam studi ini.

Teori keagenan menjelaskan bahwa hubungan agensi muncul ketika satu orang atau lebih (principal) memperkerjakan orang lain (agent) untuk memberikan satu jasa dan kemudian mendelegasikan wewenang pengambilan keputusan kepada agen tersebut (Jensen dan Meckling 1976). Pendelegasian wewenang akan menimbulkan konflik akibat dari benturan kepentingan yang menyangkut dengan aktivitas keputusan perusahaan. Konflik agensi dapat diminimumkan dengan suatu mekanisme pengawasan yang dapat mensejajarkan kepentingan-kepentingan tersebut sehingga timbul biaya keagenan.

Teori agensi menyatakan bahwa konflik keagenan dapat diatasi dengan mekanisme kontrol peningkatan pendanaan dengan hutang. Hal ini bermakna bahwa rasio ekuitas-aset yang rendah atau leverage yang tinggi di struktur modal akan mengurangi biaya agensi dari ekuitas luar, dan akan meningkatkan nilai perusahaan dengan menahan, mendorong atau menarik manajer untuk bertindak lebih untuk menegakkan kepentingan pemegang saham (Berger dan Di Patti 2006). Oleh karena itu, secara teoritis, struktur modal memiliki pengaruh pada meningkatnya nilai perusahaan. 


\section{Struktur Modal dalam Konteks Teori Keagenan}

Teori trade-off menyebutkan bahwa penentuan struktur modal tidak terlepas dari masalah keagenan terutama pada keputusan pendanaan. Masalah utama dalam keputusan pendanaan adalah menetapkan struktur modal yang diasumsikan memberikan hasil terbaik untuk memutuskan berapa jumlah dana yang ditambahkan untuk mendukung kebijakan perusahaan sehingga kinerja perusahaan dapat meningkat dalam kompleksitas kegiatan dengan resiko. Keputusan pendanaan ini pada kerangka teori agensi tidak lepas dari benturan kepentingan agen dan prinsipal.

Pada pendekatan teori agensi, Jensen dan Meckling (1976) menjelaskan bahwa sebagaimana perusahaan yang memerlukan dana tambahan untuk mendukung kebijakan perusahaan sebagai organisasi yang dicirikan oleh prilaku individu atau kelompok yang diarahkan untuk mencapai sasaran, maka organisasi tidak terlepas dari persinggungan antar kepentingan individu atau kelompok. Oleh karena itu komposisi struktur modal harus pula mempertimbangkan hubungan antara perusahaan, kreditur maupun pemegang saham yang dapat meminimalkan konflik yang menimbulkan agency cost.

Ada beberapa alternatif untuk mengurangi agency cost dalam konteks struktur modal, salah satunya teori agensi menunjukkan bahwa pilihan struktur modal dapat membantu mengurangi biaya agensi. Berdasarkan teori agensi, pilihan hutang yang tinggi akan mengurangi biaya agensi dari luar ekuitas dan meningkatkan nilai perusahaan dengan membatasi atau mendorong manajer untuk bertindak lebih demi kepentingan pemegang saham (Saltaji 2013).

Hart dan Marshall (2013) dan Grossman dan Hart (1982) menjelaskan bahwa hutang dapat mendisplinkan para manajer untuk bekerja keras dan membuat keputusan investasi yang lebih baik. Pembiayaan perusahaan untuk menambah modal baru melalui hutang membuat manajer lebih berhati-hati menggunakannya. Jensen dan Meckling (1976) berpendapat bahwa penggunaan hutang dapat membantu menekan konflik keagenan antara manajer dan pemegang saham. Jensen (1986) mengatakan hutang dapat digunakan untuk mengendalikan penggunaan arus kas bebas yang berlebihan oleh manajer yang menyebabkan ketidak-efisienan pengelolaan oleh manajemen. Berdasarkan pada penjelasan ini kebijakan hutang memiliki peranan penting dalam mengurangi konflik keagenan.

Literatur empiris tentang struktur modal lembaga keuangan mikro masih terus berkembang dan membutuhkan penelitian lebih lanjut. Studi ini telah di lakukan di beberapa negara dengan beragam variasi. Kyereboah-Coleman (2007b) menggunakan 54 LKM di Ghana untuk mengidentifikasi dampak struktur modal pada kinerja jangkauan mikro dan hasil mereka menunjukkan bahwa hutang (long term debt) berpengaruh tehadap kinerja (outreach dan default rate). Sebagian besar lembaga keuangan mikro menerapkan leverage yang tinggi dan membiayai operasi mereka dengan hutang jangka panjang daripada hutang jangka pendek. Juga, lembaga keuangan mikro yang sangat leveraged tampil lebih baik dengan menjangkau lebih banyak pelanggan, menikmati skala ekonomi, dan karena itu lebih mampu menangani moral hazard dan adverse selection, dan meningkatkan kemampuan mereka untuk menangani risiko. Hal ini bermakna hutang sebagai proporsi terbesar (leverage) dari struktur modal telah meningkatkan jumlah pelanggan yang terlayani dan jangkauan pelanggaan ke wilayah lain.

Hoque et al. (2011) meneliti komersialisasi dan perubahan dalam struktur modal di keuangan mikro pada 24 LKM di negara Amerika Tengah dan Selatan, Afrika, Eropa Timur, dan Asia. Hoque et al. (2011) menemukan bukti bahwa peningkatan penggunaan hutang komersial dan pembiayaan ekuitas menyebabkan produktivitas yang lebih rendah bagi LKM karena konversi yang lebih rendah dari penabung ke peminjam yang didefinisikan sebagai tingkat imbal hasil (yield rate). Tingkat yield atau penurunan produktivitas yang mengarah ke penurunan operasional swasembada.

Melanjutkan studi dibidang ini, Bogan (2012) meneliti struktur modal dan hubungannya dengan keberlangsungan. Hasil studi menunjukkan variabel tahapan daur hidup secara signifikan terkait dengan kedua operasional swasembada dan efisiensi. Bogan (2012) menemukan bukti kausal untuk mendukung pernyataan bahwa penggunaan hibah dijalankan menurunkan operasional swasembada. Ini memperkuat pandangan bahwa penggunaan jangka panjang dari hibah mungkin berhubungan dengan operasi tidak efisien karena kurangnya tekanan persaingan yang terkait dengan menarik pendanaan pasar.

\section{Penelitian Terdahulu dan Pengembangan Hipotesis}

Keputusan struktur modal adalah penting untuk setiap organisasi bisnis, termasuk lembaga keuangan mikro karena melibatkan pertimbangan antara resiko dan tingkat pengembalian yang berdampak pada keberlangsungan keuangan lembaga. Saat ini BPR memiliki jangkauan yang semakin luas pada sumber keuangan yang mereka miliki, yang memberikan diversifikasi pendanaan dan membuatnya lebih kompleks pada keputusan struktur modal. Pengambilan keputusan struktur modal yang lebih baik akan meminimalkan risiko, memaksimalkan fleksibilitas keuangan, dan mendorong solvabilitas jangka panjang. 
Sumber permodalan di BPR berasal dari internal yaitu ekuitas pemilik berupa modal sendiri yang dapat berbentuk modal saham, cadangan, laba yang ditahan atau laba yang tidak dibagi, dan dari modal ekternal yaitu tabungan, deposito, pinjaman dan hibah. Keputusan penggunaan modal internal dan ekternal pada struktur modal perlu dipertimbangkan dengan baik karena menyangkut resiko yang mungkin terjadi dan lembaga harus menanggung dampak dari keputusan tersebut yaitu pada keberlangsungan keuangan. Oleh karena itu menurut Weston dan Brigham (1990), salah satu keputusan penting manajer keuangan agar tetap berdaya saing tinggi dalam jangka pajang adalah keputusan struktur modal.

Keputusan struktur modal di BPR tidak terlepas dari benturan kepentingan dari berbagai pilihan diversifikasi pendanaan. Keputusan diversifikasi struktur modal ini nantinya akan berkaitan dengan biaya agensi yaitu bagaimana keputusan ini bisa memperkecil atau memperbesar biaya agensi akibat dari intervensi pihak-pihak yang berkepentingan pada struktur modal. Pihak-pihak yang mengintervensi struktur modal di BPR ini berasal dari internal dan eksternal yaitu pemilik modal dan manajer yang berasal dari internal, pemilik hutang dan pemerintah (BI dan OJK) yang berasal dari ekternal.

Terkait dengan intervensi pihak internal maka pemilik modal umumnya akan mengawali keputusan struktur modal dengan pendanaan internal yang berasal dari modal pemilik. Namun demikian, penentuan besarnya modal disetor terikat dengan intervensi pihak eksternal yaitu dengan peraturan BI (PBI) No.8/26/2006 pasal 4 yang memberlakukan setoran modal minimum berdasarkan zonasi wilayah dimana BPR tersebut didirikan. Pada perspektif teori agensi, semakin besar modal pemilik maka semakin besar biaya agensi. Bagaimanapun, manajer memiliki perberbedaan kepentingan dengan pemilik yang memunculkan biaya pengawasan dan monitoring terhadap prilaku self-interest manajer. Pemilik memiliki resiko sepenuhnya terhadap kegagalan akibat dari tindakan manajemen yang merugikan kepentingan pemilik. Oleh karena itu, semakin besar modal ekuitas semakin besar biaya agensi, karena manajer tidak akan memaksimalkan nilai ekuitas pemegang saham (Jensen dan Meckling 1976), sehingga berdampak negatif pada keberlangsungan. Dengan demikian, hipotesis 1 pada riset ini adalah: $\mathrm{H}_{1}$ : Ekuitas berpengaruh negatif pada keberlangsungan.

Pendanaan internal lainnya adalah bersumber dari laba. Laba merupakan bagian dari cadangan umum, cadangan tujuan dan laba ditahan yang berfungsi untuk memperkuat modal BPR (Bank Indonesia 2010). Dana ini diperoleh dari sebagian hasil usaha yang digunakan untuk tujuan tertentu dan tidak dibagikan kepada pemilik saham sesuai dengan persetujuan RUPS BPR, yang umumnya digunakan untuk meningkatkan modal, memenuhi kewajiban, jaminan kerugian dan perluasan aktivitas yang dapat digunakan sewaktu-waktu apabila BPR membutuhkan dana tersebut (Bank Indonesia 2010). Keputusan RUPS menjadi kontrol manajemen terhadap kemungkinan manajer menyalahgunakan kekuasaan pengambilan keputusan pada penggunaan laba, karena dana tersebut telah ditetapkan tujuannya dan dapat diambil sewaktu-waktu bila dibutuhhkan. Dengan demikian, laba memberikan dampak positif pada keberlangsungan. Atas dasar tersebut hipotesis 2 adalah:

$\mathrm{H}_{2}$ : Laba berpengaruh positif pada keberlangsungan.

Sumber modal yang berasal dari fungsi intermediaris adalah akses dana pasar/masyarakat dalam bentuk deposito dan tabungan (Bank Indonesia 2010). Tabungan dan deposito adalah hutang jangka pendek yang likuid dengan kewajiban pembayaran bunga (Ikatan Akuntan Indonesia 2009). Suku bunga rata-rata tabungan dan deposito BPR saat ini diatas bank umum. Kewajiban pembayaran bunga diatas rata-rata akan mempengaruhi manajer menggunakan sumber modal ini secara efisien. Selain itu, lembaga penjamin simpanan (LPS) menjamin tabungan/deposito nasabah maksimum 2 miliar per nasabah. Akses asuransi/jaminan ini dapat meningkatkan pergeseran risiko atau manajemen risiko menjadi longgar, berpotensi mengurangi resiko manajer sehingga biaya agensi menjadi menurun (Williams 1987). Dengan demikian, tabungan dan deposito berdampak positif meningkatkan keberlangsungan. Hipotesis ke 3 dan 4 adalah:

$\mathrm{H}_{3}$ : Tabungan berpengaruh positif pada keberlangsungan.

$\mathrm{H}_{4}$ : Deposito berpengaruh positif pada keberlangsungan.

Transformasi mengharuskan BPR tidak dapat tanpa akuisisi hutang yang berasal dari pinjaman yaitu pinjaman diterima (lingkage), pinjaman subordinasi dan modal pinjaman (quasi), dan ini akan melibatkan pihak eksternal yaitu pemegang hutang yang akan mengintervensi manajemen. Pemegang hutang akan menentukan tingkat bunga, waktu pembayaran dan memberikan tekanan untuk resiko kegagalan pembayaran hutang pada ancaman likuidasi lembaga. Teori trade-off menyatakan bahwa keputusan modal hutang terkait dengan trade-off keuntungan dan kerugian dari hutang (Besley dan Brigham 2008). Manfaat dari utang menjadi jelas dalam bagaimana manajemen efisien menggunakan hak kontrol atas aktivitas perusahaan. Sebagaimana yang dikatakan 
Jensen (1986), peningkatan leverage mendisiplinkan perilaku manajemen, meningkatkan komitmen mereka terhadap manajemen perusahaan yang lebih efisien, sehingga hipotesis 5, 6 dan 7 adalah:

$\mathrm{H}_{5}$ : Pinjaman diterima (lingkage) berpengaruh positif pada keberlangsungan.

$\mathrm{H}_{6}$ : Pinjaman subordinasi berpengaruh positif pada keberlangsungan.

$\mathrm{H}_{7}$ : Modal pinjaman/quasi berpengaruh positif pada keberlangsungan.

Sumber modal eksternal lainnya di BPR adalah hibah. Dana hibah adalah sumbangan yang diterima yang memperkuat modal dan tidak besiko. Hibah menjadikan lembaga tidak mandiri karena sifat ketergantungan memberi efek tidak mendisiplinkan manajer dengan tidak menggunakan sumber daya yang tidak beresiko secara tidak efisien. Dengan demikian semakin besar dana hibah semakin tinggi biaya agensi dan berdampak negatif pada keberlangsungan.

$\mathrm{H}_{8}$ : Hibah berpengaruh negatif pada keberlangsungan.

\section{Metoda Penelitian}

\section{Data dan Sampel}

Jenis penelitian ini merupakan penelitian kuantitatif dan data yang digunakan adalah data sekunder berupa laporan keuangan dan laporan kepemilikan untuk tahun 2012-2014. Populasi penelitian adalah1.643 BPR di 33 propinsi yang tersebar di setiap kabupaten/kota di Indonesia. Menggunakan rumus Rao (1966) dengan tingkat moe 5 persen di dapat sampel penelitian sebanyak 322 BPR. Metode pengambilan sampel ditetapkan berdasarkan sampel proporsional di propinsi dan kabupaten. Data di dapat dari situs OJK, www.ojk.go.id, situs Bank Indonesia www.bi.go.id berupa laporan keuangan dan data kepemilikan di collecting dari lembaga OJK untuk tahun 20122014. Periode sebelum tahun 2012 tidak dimasukkan dalam pengamata karena missing data sedangkan setelah periode 2014 ada perbedaan kebijakan dan peraturan.

\section{Definisi dan Pengukuran Variabel}

\section{Variabel dependen}

Keberlangsungan keuangan mikro didefinisikan sebagai kemampuan lembaga untuk tetap hidup dimasa yang akan datang (Robinson 2001). Keberlangsungan diproksikan dengan Financial Self-Sufficiency (FSS). FSS menunjukkan kecukupan pendapatan yang dihasilkan untuk menutupi biaya langsung, termasuk biaya pembiayaan, penyisihan aktiva produktif, biaya operasional serta biaya tidak langsung (Ledgerwood 2013). Rumus yang digunakan adalah:

$$
\mathrm{FSS}=\frac{\text { Pendapatan Operasional }}{\text { Biaya operasional }+ \text { biaya modal }+ \text { penyisihak aktiva produktif }+ \text { biaya non operasional }}
$$

\section{Variabel independen}

Equity-relative to asset mengukur seberapa banyak lembaga yang dibiayai oleh modal ekuitas terhadap total assetnya. Lembaga dengan rasio ekuitas/asset yang lebih tinggi adalah kurang berisiko karena tidak ada kewajiban yang harus dibayarkan. Perhitungannya adalah sebagai berikut:

$$
\text { Equity-relative to asset }=\frac{\text { total Equity }}{\text { total asset }} \times 100 \%
$$

Earning- relative to asset mengukur berapa banyak lembaga yang dibiayai oleh saldo laba terhadap total assetnya. Lembaga dengan rasio laba/asset yang lebih tinggi adalah kurang berisiko. Rumus yang digunakan adalah:

$$
\text { Earning- relative to asset }=\frac{\text { saldo laba }}{\text { total asset }} \times 100 \%
$$

Saving-relative to asset mengukur berapa banyak lembaga yang dibiayai oleh saving terhadap total assetnya. Lembaga dengan rasio saving/asset yang lebih rendah adalah kurang berisiko dibandingkan dengan rasio yang lebih tinggi. Perhitungannya adalah sebagai berikut:

$$
\text { Saving-relative to asset }=\frac{\text { total saving }}{\text { total asset }} \times 100 \%
$$


Deposit-relative to asset mengukur berapa banyak lembaga yang dibiayai oleh deposito terhadap total assetnya. Perusahaan dengan rasio deposit/asset yang lebih rendah adalah kurang berisiko dibandingkan dengan rasio yang lebih tinggi. Perhitungannya adalah sebagai berikut:

$$
\text { Deposit-relative to asset }=\frac{\text { total deposit }}{\text { total asset }} \times 100 \%
$$

Linkage capital-relative to asset asset mengukur berapa banyak lembaga yang dibiayai oleh modal linkage terhadap total assetnya. Modal linkage adalah pinjaman yang diperoleh dari kerjasama bank-bank komersial dengan BPR untuk pengembangan kredit keuangan mikro. Perusahaan dengan rasio Linkage capital/asset yang lebih rendah adalah kurang berisiko dibandingkan dengan rasio yang lebih tinggi. Perhitungannya besarnya modal linkage terhadap total assetnya adalah sebagai berikut:

$$
\text { Linkage capital-relative to asset }=\frac{\text { total linkage }}{\text { total asset }} \times 100 \%
$$

Subordinated debt relative to asset adalah mengukur berapa banyak lembaga yang dibiayai oleh pinjaman subordinasi (pinjaman lunak) terhadap total assetnya. Perusahaan dengan rasio subordinated debt/asset yang lebih rendah adalah kurang berisiko dibandingkan dengan rasio yang lebih tinggi. Hutang ini biasanya bersifat menengah atau jangka panjang. Perhitungannya adalah sebagai berikut:

$$
\text { Subordinated debt-relative to asset }=\frac{\text { Subordinated debt }}{\text { total asset }} \times 100 \%
$$

Quasy capital relative to asset mengukur berapa banyak lembaga yang dibiayai oleh modal pinjaman (quasy capital) terhadap total assetnya. Quasy-capital adalah pinjaman yang didukung oleh instrumen atau warkat. Perusahaan dengan rasio quasy-capital/asset yang lebih rendah adalah kurang berisiko dibandingkan dengan rasio yang lebih tinggi. Perhitungannya besarnya quasy-capital terhadap total assetnya adalah sebagai berikut:

$$
\text { Quasy-capital -relative to asset }=\frac{\text { total Quasy-capital }}{\text { total asset }} \times 100 \%
$$

Grant relative to asset adalah mengukur berapa banyak lembaga yang dibiayai oleh modal sumbangan terhadap total assetnya. Lembaga dengan rasio grant/asset yang tinggi adalah kurang berisiko karena tidak ada kewajiban yang harus dibayarkan. Besarnya pendanaan grant terhadap asset lembaga di rumuskan sebagai berikut:

$$
\text { Grant-relative to asset }=\frac{\text { grant }}{\text { total asset }} \times 100 \%
$$

\section{Metode Analisis Data dan Pengujian Hipotesis}

Penelitian ini menggunakan alat analisis Strucural Equation Modelling (SEM) dengan program WarpPLS versi 4.0. Penelitian sebelumnya menggunakan OLS (Bogan 2012, Hoque et al. 2011, Kyereboah-Coleman 2007a) dan multiple regression (Sekabira 2013) dengan analisa jalur. WarpPLS digunakan karena kelebihan menyelesaikan persoalan seperti data yang tidak terdistribusi normal secara multivariate. Spesifikasi model ekonometrik adalah:

$\mathrm{FSS}_{\mathrm{i}}=\alpha_{\mathrm{o}}+\beta 1$ Ekuitas $_{\mathrm{i}}+\beta 2 \mathrm{Laba}_{\mathrm{i}}+\beta 3 \mathrm{Tab}_{\mathrm{i}}+\beta 4$ Dep $_{\mathrm{i}}+\beta 5$ lingkage $_{\mathrm{i}}+\beta 6 \mathrm{Sub}_{\mathrm{i}}+\beta 7 \mathrm{Quasi}_{\mathrm{i}}+\beta 8 \mathrm{Hibah}_{\mathrm{i}}+\varepsilon_{\mathrm{i}}$

Di manan, FSS adalah keberlansungan keuangan, Ekuitas adalah modal ekuitas, Laba adalah laba dari pendapatan, Tab adalah tabungan, Dep adalah deposito, lingkage adalah pinjaman lingkage, Sub adalah pinjaman subordinasi, Quasi adalah pinjaman modal/quasi dan hibah adalah hibah/grant.

\section{Hasil dan Pembahasan}

\section{Hasil Pengujian Hipotesis}

Hasil evaluasi model pengukuran menunjukkan indicator weight (pembobotan) yang signifikan untuk semua variabel yaitu p kurang dari 0.05 dan multikolinearitas (VIF) lebih kecil dari 3,3 (Kock 2014) lihat lampiran 2. Selanjutnya evaluasi model struktural menunjukkan output 'model fit dan quality indicies' yaitu APC, ARS dan AARS adalah signifikan yang sesuai dengan rule of thumb-nya pada $\mathrm{P}<0,05$ dan AVIF dan AFVIF $<3,3$ sehingga model penelitian fit (lihat Tabel 1). 
Tabel 1. Model fit dan quality indices

\begin{tabular}{ll}
\hline Model fit dan quality indices & \\
\hline Average path coefficient (APC) & $0.093, \mathrm{P}<0.001$ \\
Average $R$-squared (ARS) & $0.244, \mathrm{P}<0.001$ \\
Average adjusted $R$-squared (AARS) & $0.238, \mathrm{P}<0.001$ \\
Average block VIF (AVIF) & 1.117, acceptable if $<=5$, ideally $<=3.3$ \\
Average full collinearity VIF (AFVIF) & 1.436, acceptable if $<=5$, ideally $<=3.3$ \\
\hline
\end{tabular}

Pada Tabel 2, R-square menunjukkan bahwa 24,4\% variansi konstruk endogen dapat dijelaskan oleh konstruk eksogen. Q-square sebesar 23,8\% menunjukkan penilaian validitas prediktif atau relevansi dari sekumpulan variabel laten prediktor pada variabel criterion. Full colinearity VIF merupakan hasil pengujian kolinearitas penuh yang meliputi multikolinearitas vertikal dan lateral (Sholihin dan Ratmono 2013). Hasil menunjukkan nilai Full colinearity VIF kurang dari 3,3 sehingga model bebas dari masalah kolinieratis.

Tabel 2. R-squared, Q-squared dan Full Colinearity VIF.

\begin{tabular}{lccccccccc}
\hline & Hibah & Ekuitas & Laba & Tab & FSS & Dep & Lingkage & Sub & Quasi \\
\hline R-squared & & & & & 0,244 & & & & \\
Adj. R-squared & & & & & 0,238 & & & & \\
Full colliniearity VIF & 1.040 & 2.283 & 2.453 & 1.227 & 1.235 & 1.438 & 1.233 & 1.003 & 1.011 \\
Q-squared & & & & & 0,264 & & & & \\
\hline
\end{tabular}

Tabel 3 dan Gambar 1 menujukkan hasil Path coefficients dan $P$ values. Jalur ekuitas-FSS menunjukkan nilai koefisien $-0,09$ dan $p=0,001$ dan signifikan dibawah $\alpha$ 0,5. Dengan demikian hipotesis 1 diterima. Hal ini bermakna bahwa ekuitas berpengaruh negatif pada keberlangsungan. Modal ekuitas akan meningkatkan biaya agensi karena prilaku self-interest manajer terhadap penggunaan arus kas bebas yang tersedia yang bersumber dari pemilik tidak digunakan secara efisien yang menyebabkan meningkatnya biaya monitoring. Seperti yang dinyatakan oleh Jensen dan Meckling (1976) bahwa perusahaan yang lebih di danai oleh ekuitas cenderung memiliki biaya agensi yang tinggi, karena manajer tidak akan memaksimalkan nilai ekuitas pemegang saham.

Tabel 3. Path coefficients dan $P$ values

\begin{tabular}{|c|c|c|c|c|c|c|}
\hline & \multicolumn{2}{|l|}{ Dependent: FSS } & $\begin{array}{l}\text { FSS, Demografi } \\
\text { Kode }=1\end{array}$ & \multicolumn{3}{|c|}{$\begin{array}{l}\text { FSS, Demografi } \\
\text { Kode }=0\end{array}$} \\
\hline & $\begin{array}{c}\text { Path } \\
\text { coefficiens }\end{array}$ & $P$ values & $\begin{array}{c}\text { Path } \\
\text { coefficiens }\end{array}$ & $P$ values & $\begin{array}{c}\text { Path } \\
\text { coefficiens }\end{array}$ & $P$ values \\
\hline \multicolumn{7}{|c|}{ Independent: } \\
\hline Ekuitas & -0.09 & $0.001 * * *$ & 0.06 & $0.04 * *$ & -0.14 & $0.003 * * *$ \\
\hline Laba & 0,42 & $<0.001 * * *$ & 0,42 & $<0.001 * * *$ & 0,40 & $<0.001 * * *$ \\
\hline Tab & 0.05 & $0.04 * *$ & 0.15 & 0.33 & -0.06 & 0.11 \\
\hline Dep & 0.04 & 0,12 & 0.01 & 0,38 & 0.11 & $0,021 * *$ \\
\hline Lingkage & 0,11 & $<0.001 * * *$ & 0,18 & $<0.001 * * *$ & $-0,17$ & $<0.001 * * *$ \\
\hline Sub & 0.02 & 0,22 & 0.03 & 0,22 & - & - \\
\hline Quasi & -0.01 & 0,39 & - & - & - & - \\
\hline Hibah & 0.02 & 0,30 & -0.000 & 0,50 & 0,052 & 0,15 \\
\hline \multicolumn{7}{|c|}{$* \operatorname{sig}=10 \%, * * \operatorname{sig}=5 \%, * * * \operatorname{Sig}=1 \%$} \\
\hline
\end{tabular}

Data menunjukkan bahwa keputusan struktur modal dari ekuitas melebihi dari ketentuan yang disyaratkan oleh peraturan BI (PBI) No.8/26/2006. Bahkan zona wilayah IV mampu menyetor hingga mencapai 100 miliar. Ekuitas untuk wilayah I DKI (syarat 5 miliar) tersebar pada 5 - 20 miliar. Wilayah II ibukota propinsi Jawa dan Bali dan wilayah kabupaten atau kota Bogor, Depok, Tanggerang, Bekasi (syarat 2 miliar) tersebar pada $2-16$ miliar. Wilayah III ibukota propinsi di luar pulau Jawa dan Bali dan wilayah pulau Jawa dan Bali diluar wilayah diatas (syarat 1 miliar) tersebar pada 1-100 miliar. Wilayah IV (syarat 500 juta) selain yang disebutkan diatas tersebar pada 500 juta -48 miliar. 
Pada perspektif teori agensi, semakin besar modal pemilik maka semakin besar biaya agensi. Pemilik memiliki resiko sepenuhnya terhadap kegagalan akibat dari tindakan manajemen yang merugikan kepentingan pemilik. Oleh karena itu, semakin besar modal ekuitas semakin besar biaya agensi. Hal ini telah didukung oleh hasil penelitian yang menunjukkan sumber modal ekuitas memberikan efek negatif pada komposisi struktur modal (patch coefficients -0,09).

Hasil jalur Laba-FSS menunjukkan nilai koefisien 0,42 dan $p<0.001$ dan signifikan dibawah $\alpha 0,5$ sehingga hipotesis 2 ditetima. Penggunaan laba yang berasal dari internal tidak memiliki resiko dibandingkan hutang. Sehingga, keputusan RUPS menjadi kontrol manajemen terhadap kemungkinan manajer menyalahgunakan kekuasaan pengambilan keputusan pada penggunaan laba, karena dana tersebut telah ditetapkan tujuannya dan dapat diambil sewaktu-waktu bila dibutuhkan. Dengan demikian, laba memberikan dampak positif pada keberlangsungan. Bagaimanapun, penggunaan laba sebagai sumber modal relatif kecil di struktur modal. Hal ini dikonfirmasi oleh data yang menunjukkan rata-rata hanya $6 \%$ selama tiga tahun.

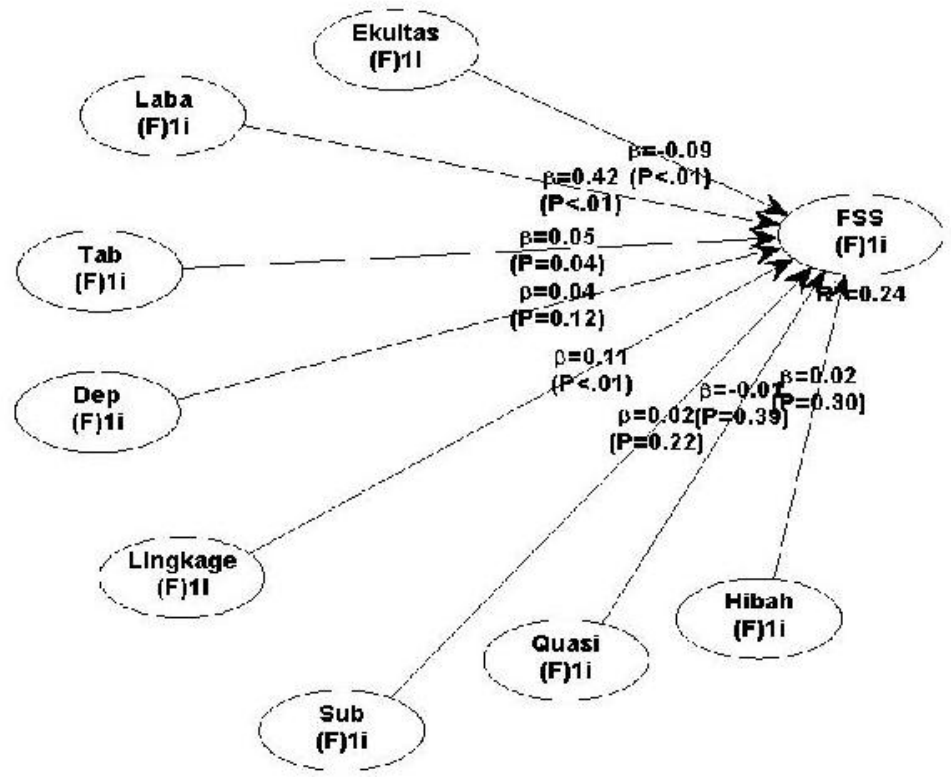

Gambar 1. Hasil Model Struktural Pengaruh Struktur Modal dengan Peran Pendanaan Individu

Jalur Tab-FSS melaporkan nilai koefisien 0,05 dan $\mathrm{p}=0.04$ dan signifikan dibawah $\alpha$ 0,5 sehingga hipotesis 3 ditetima. Sedangkan jalur Dep-FSS menunjukkan nilai koefisien 0.04 dan $p=0,12$ dan tidak signifikan dibawah $\alpha$ 0,5 yang menyimpulkan hipotesis 4 ditolak. Hasil telah menunjukkan tabungan berefek positif pada keberlangsungan artinya keputusan manajemen pada penggunaan sumber modal ini menyebabkan manajer harus menjaga arus kas yang cukup apabila deposan menarik simpanannya pada sewaktu-waktu dan menjaga kepercayaan deposan untuk menghindari berpindahnya deposan pada bank lain. Kewajiban pembayaran bunga diatas rata-rata akan mempengaruhi manajer menggunakan sumber modal ini secara efisien dan memaksa manajer untuk meningkatkan pemberian portofolio kredit baik pada volume maupun skala kredit yang bisa mengoptimalkan return dan menghasilkan kas. Berbeda hal nya dengan deposito ternyata tidak sesuai dengan yang dihipotesiskan. Deposito adalah modal terbesar di struktur modal namun tidak berpengaruh pada keberlangsungan. Hal ini menginformasikan ada peran dari variabel lain pada jalur ini hingga deposito berpengaruh pada keberlangsungan.

Hasil jalur Lingkage-FSS menunjukkan nilai koefisien 0,11 dan $\mathrm{p}<0.001$ dan signifikan dibawah $\alpha 0,5$ sehingga hipotesis 5 ditetima. Hal ini memberi keyakinan bahwa pinjaman lingkage memberikan efek yang lebih besar untuk mendisiplinkan manajer yang bertangungjawab pada keberlangsungan lembaga. Kehadiran hutang mewajibkan manajer untuk membayar suku bunga dan memenuhi tenggat waktu dan dengan demikian meningkatkan komitmen mereka terhadap manajemen perusahaan yang lebih efisien.

Dana lingkage meningkat tajam pada tahun 2013 dan 2014. Hal ini dipengaruhi oleh peraturan BI (PBI) No. 14/22/PBI/2012 tentang Pemberian Kredit atau Pembiayaan Oleh Bank Umum dan Bantuan Teknis Dalam Rangka Pengembangan Usaha Mikro, Kecil dan Menengah. Berdasarkan peraturan ini total capaian rasio minimal kredit atau pembiayaan kepada UMKM oleh tiap bank umum harus mencapai 20 persen hingga tahun 2018. Dengan adanya peraturan ini, bank umum menyalurkan modalnya ke UMKM melalui kerjasama ligkage dengan BPR untuk mencapai rasio minimal kredit atau pembiayaan kepada UMKM secara bertahap. Namn demikian, BPR perlu berhati-hati pada peningkatan signifikan dana lingkage karena menyangkut dengan biaya modal yang tinggi. 
Berbeda hal nya dengan hasil jalur Sub-FSS dan Quasi-FSS yang memberikan hasil yang tidak signifikan. Hal ini disebabkan karena kecilnya sumber modal pinjaman subordinasi dan pinjaman modal /quasi yaitu rata-rata dibawah $0.51 \%$ sehingga tidak berpengaruh pada keberlangsungan lembaga. Dengan demikian hipotesis 6 dan hipotesis 7 ditolak. Begitu juga dengan jalur Hibah-FSS yang menginformasikan bahwa tidak berpengaruh pada keberlangsungan. Penggunaan dana hibah juga menunjukkan rata-rata $2,48 \%$ yang menggambarkan bahwa lembaga tidak tergantung pada sumber dana hibah sehingga hipotesis 8 di tolak.

Hasil telah menunjukkan Ekuitas, Laba, Tab dan lingkage memberikan pengaruh positif pada keberlangungan keuangan, yang ditunjukkan oleh nilai FSS $\geq 110 \%$ yaitu sebesar rata-rata 93\% pada tahun 2012, 92\% pada tahun 2013 dan 86\% pada tahun 2014. Hal ini dapat diartikan lembaga mampu mencapai tingkat kecukupan keuangan untuk menutupi biaya dari kegiatan operasionalnya untuk mencapai keberlangsungan lembaga.

Secara umum hasil riset konsisten dengan perspektif teori agensi yang menyatakan bahwa manajer perusahaan yang di danai oleh hutang cenderung untuk terlibat dalam strategi pergeseran resiko ketika mereka memiliki arus kas bebas yang tersedia. Hal ini dapat diartikan hutang memberi efek mendisiplinkan manajer untuk menghasilkan arus kas dan menggunakan arus kas secara efisien karena kewajiban pembayaran bunga dan risiko kegagalan akan meningkatkan komitmen mereka terhadap manajemen yang lebih efisien untuk mencapai keberlangsungan lembaga. Dengan demikian, pendanaan hutang dapat menjadi mekanisme bonding sebagai alat kontrol manajemen dalam upaya mencapai keberlangsungan.

Pada perspektif kebijakan, pemerintah berkewajiban mengatur BPR dengan penetapan modal minimum. Berdasarkan peraturan BI (PBI) No 8/18/PBI/2006 modal adalah hal krusial bagi BPR karena memiliki leverage yang tinggi, sehingga BPR harus memiliki kecukupan modal untuk dapat beroperasi secara sehat. BPR wajib menyediakan modal minimum sebesar $8 \%$ (delapan perseratus) dari aktiva tertimbang menurut risiko. Namun demikian, lembaga cenderung memegang lebih banyak modal ketika mereka meminjamkan dalam pasar yang lebih kompetitif, untuk melakukan preventif dan tindakan menjaga biaya dari kesulitan keuangan, kebangkrutan, atau likuidasi. Hal ini dapat dikonfirmasi pada rata-rata rasio kecukupan modal (CAR) sebesar 26,58\% pada tahun 2012, 26,02\% pada tahun 2013 dan 25,96\% pada tahun 2014. Bagaimanapun, BI dan OJK hanya mengintervensi kebijakan modal disetor dan modal minimum karena menyangkut dengan daya saing dan likuiditas lembaga, sedangkan pilihan, komposisi dan besarnya struktur modal ditentukan sendiri oleh pihak internal BPR.

Hasil penelitian ini telah memberikan hasil yang sama dengan penelitian terdahulu Kyereboah-Coleman (2007b) yang menguji dampak struktur modal terhadap kinerja lembaga keuangan mikro di Ghana dan menemukan hubungan yang positif pengaruh hutang terhadap kinerja LKM. Namun demikian riset ini tidak sepaham dengan (Hoque et al. (2011) yang tidak mendukung komersialisasi lembaga atau akses dana pasar di keuangan mikro.

\section{Analisis Efek Demografi}

Analisis ini berguna untuk melihat perbedaan efek demografi untuk kelompok sampel di pulau Jawa dan Bali (kode1) sebanyak 690 observasi dengan di luar pulau Jawa dan Bali (kode 0) sebanyak 690 observasi. Batasan yang dipilih menghapus variasi indikator quasi (modal pinjaman) untuk pengujian kode 1 dan 0 , subordinasi untuk kode 0 sehingga indikator di lepas dari model. Hasil menunjukkan (Tabel 2) efek demografi di pulau Jawa dan Bali menyebabkan Tab,Dep, Sub dan Hibah tidak berpengaruh pada keberlangsungan, Ekuitas sig pada $\alpha=5 \%$, Laba dan Lingkage sig pada $\alpha=1 \%$. Efek demografi di luar pulau Jawa dan Bali menunjukkan Ekuitas, Laba dan Lingkage sig pada $\alpha=1 \%$, Dep sig pada $\alpha=5 \%$ sedangkan Tab dan Hibah tidak signifikan.

Efek Ekuitas berbeda di kedua wilayah. Hal ini disebabkan pemilik modal telah mampu secara ketat mensupervisi manajemen untuk penggunaan modal ekuitas dibandingkan di luar pulau Jawa dan Bali yang menyebabkan manajer tidak menggunakan ekuitas secara efisien terhadap penggunaan sumber modal ini. Laba dan lingkage memberi efek yang sama di kedua wilayah karena penggunaan laba dikontrol oleh RUPS dan lingkage adalah pinjaman jangka panjang yang sesuai dengan teori agensi yang menyatakan hutang akan mendisiplinkan manajer untuk manajemen yang lebih efisien dan pada penggunaan arus kas terhadap tekanan likuidasi dan ancaman kebangkrutan. Tab memberikan hasil yang sama tidak berpengaruh yang bertentangan dengan teori sementara Dep hasil efek nya berbeda. Dep adalah sumber modal terbesar dan mahal yang harusnya berpengaruh positif seperti di luar pulau Jawa dan Bali.

\section{Analisis Sensitivitas}

Untuk memperoleh validitas internal, pengujian menggantikan indikator FSS dengan ROA. ROA mencerminkan kemampuan aktiva produktif untuk menghasilkan pendapatan sebagai signal harapan hidup dimasa depan. Hasil di Tabel 4 menunjukkan model fit terpenuhi APC, ARS dan AARS signifikan dan AFVIF bebas multikolinearitas. Variabel Ekuitas, Laba, Tab dan Dep menunjukkan signifikansi yang kuat $\mathrm{P}<0.001$. Berbeda dengan pengujian 
utama, hasil sensitivitas menunjukkan Dep berpengaruh pada keberlangsungan. Namun demikian Tab dan Dep berbeda tanda dengan yang dihipotesiskan. Sementara itu Sub, Quasi dan Hibah mencatat hasil yang sama seperti pengujian utama. Secara keeluruhan hasil pengujian sensitivitas tidak jauh berbeda dengan pengujian utama.

Tabel 4. Model fit dan quality indices, Path coefficients dan $P$ values

\begin{tabular}{llll}
\hline Model fit dan quality indices & APC $=0.114, \quad$ & $\mathrm{P}<0.001$ & \\
& ARS $=0.304$, & $\mathrm{P}<0.001$ & \\
& AARS $=0.298$, & $\mathrm{P}<0.001$ & \\
& AVIF $=1.278$, & Ideally $<=3.3$ & \\
& AFVIF $=1.456$, & Ideally $<=3.3$ & \\
Path coefficients dan P values & Ekuitas-Roa & -0.101 & $\mathrm{P}<0.001$ \\
& Laba-Roa & 0.421 & $\mathrm{P}<0.001$ \\
& Tab-Roa & -0.096 & $\mathrm{P}<0.001$ \\
& Dep-Roa & -0.175 & $\mathrm{P}<0.001$ \\
& Lingkage-Roa & 0.044 & $\mathrm{P}=0.068$ \\
& Sub-Roa & 0.035 & $\mathrm{P}=0.120$ \\
& Quasi-Roa & -0.012 & $\mathrm{P}=0.336$ \\
& Hibah-Roa & 0.028 & $\mathrm{P}=0.167$ \\
\hline
\end{tabular}

\section{Simpulan}

Riset ini menginvestigasi pengaruh struktur modal yang terdiri dari 8 variabel terhadap keberlangsungan di lembaga keuangan mikro formal/teregulasi. Secara keseluruhan hasil menunjukkan bahwa struktur modal dengan variabel laba, tabungan dan pinjaman lingkage memberi pengaruh positif pada keberlangsungan dan ekuitas berpengaruh negatif pada keberlangsungan. Sementara itu deposito, pinjaman subordinasi, modal pinjaman/quasi dan hibah tidak berpengaruh pada keberlangsungan. Hasil mendukung transformasi di keuangan mikro dan pendekatan komersial untuk perubahan struktur modal.

Sumber modal ekuitas akan meningkatkan biaya agensi karena meningkatnya biaya monitoring dan prilaku self-interest manajer terhadap penggunaan arus kas bebas yang tersedia. Sehingga, penelitian ini merekomendasikan BPR perlu berhati-hati dan mempertimbangkan meningkatkan dana ekuitas karena akan berefek negatif pada keberlangsungan. Sementara itu, tabungan memberikan pengaruh positif, hal ini memberikan keyakinan bahwa meningkatnya resiko modal akan mendisiplinkan prilaku manajer untuk bertanggungjawab menghasilkan kas dan penggunaan arus kas bebas untuk bisa menutupi biaya modal yang timbul. Dengan demikian, hasil ini merekomendasikan BPR untuk tetap mempertahankan akses dana pada tabungan.

Deposito adalah modal terbesar di struktur modal namun tidak berpengaruh pada keberlangsungan. Hal ini menginformasikan ada peran dari variabel lain pada jalur ini hingga deposito berpengaruh pada keberlangsungan dan ini dapat menjadi agenda penelitian mendatang. Begitu juga $R$-square sebesar $24,4 \%$ menunjukkan ada variabel-variabel lain yang mempengaruhi keberlangsungan di lembaga keuangan mikro seperti struktur modal, tata kelola peruahaan, kompetisi, resiko dan lain-lain.

Saat ini dan ke depan perlu menjadi perhatian BPR, kebijakan pemerintah menekan suku bunga pinjaman KUR dari lending rate menjadi sigle digit pada bank-bank umum sangat berdampak pada BPR terutama dalam persaingan pasar. Kompetisi ini mengharuskan BPR mengambil kebijakan struktur modal yang bisa menekan suku bunga mereka menjadi single digit agar mampu berkompetisi dengan bank umum. Hal ini menjadi pekerjaan berat bagi BPR karena pola penyebaran BPR berada di daerah yang sebelumnya telah padat bank-bank umum dan kecenderungan masyarakat membuka account dengan kemudahan fasilitas bank umum semakin mempersulit BPR menghimpun dana dari masyarakat.

\section{Daftar Referensi}

Abor, J. 2005. The effect of capital structure on profitability: an empirical analysis of listed firms in Ghana. The Journal of Risk Finance 6 (5): 38-47.

Bank Indonesia. 2010. Pedoman akuntansi bank perkreditan rakyat. Edisi 1. Jakarta: Bank Indonesia 
Berger, A. N., dan E. B. Di Patti. 2006. Capital structure and firm performance: a new approach to testing agency theory and an application to the banking industry." Journal of Banking \& Finance 30 (4): 1065-1102.

Bertomeu, J., A. Beyer, dan R. A. Dye. 2011. Capital structure, cost of capital, and voluntary disclosures. The Accounting Review 86 (3): 857-886.

Besley, S., dan E. F. Brigham. 2008. Essentials of managerial finance. United States of America: Thomson SouthWestern.

Bogan, V. L. 2012. Capital structure and sustainabiliy: an empirical study of microfinance instituion. The Review of Economics and Statistics 94 (4): 1045-1058.

Cassar, G., dan S. Holmes. 2003. Capital structure and financing of SMEs: Australian evidence. Accounting and Finance 43 (2): 123-147.

Charitonenko, S., dan I. Afwan. 2003. Commercialization of microfinance: Indonesia. Manila: Asian Development Bank.

Christen, R. P. 2001. Commercialization and mission drift. The transformation of microfinance in Latin America. CGAP Occasional Paper No. 5. Washington, DC.

Christen, R. P., dan D. Drake. 2002. Commercialization: the new reality of microfinance. In The commercialization of microfinance: balancing business and development, edited by D. Drake., dan E. Rhyne.

Dehejia, R., H. Montgomery, dan J. Morduch. 2012. Do interest rates matter? credit demand in the Dhaka slums. Journal of Development Economics 97 (2): 437-449.

de Aghion, B. A., dan J. Morduch. 2005. The economics of microfinance. Cambridge, Massachusetts London, England: The MIT Press.

Frank, C. 2008. Stemming the tide of mission drift: microfinance transformations and the double bottom line. New York: Women World Banking (WWB).

Grossman, S. J., dan O. D. Hart. 1982. Corporate financial structure and managerial incentives. In The economics of information and uncertainty, edited by ed. John McCall, 107-140. Chicago: University of Chicago Press.

Guntz, S. 2011. Sustainability and profitability of microfinance institutions. Research Paper In International Finance and Economics: Center for Applied International Finance and Development (CAIFD).

Harris, M., dan A. Raviv. 1990. Capital structure and the informational role of debt. The Journal of Finance XLV (2): 321-349.

Helms, B. 2006. Access for all: building inclusive financial systems, capturing 10 year of CGAP experience. Consultative Group to Assist the Poor (CGAP): World Bank.

Hoque, M., M. Chishty, dan R. Halloway. 2011. Commercialization and changes in capital structure in microfinance: an innovation or wrong turn? Managerial Finance 37 (5): 414-425. doi: 10.1108/03074351111126906 10.1108/H-11-2013-0073.

Hulme, D., dan P. Mosley. 1966. Finance against poverty, 1 and 2. London: Routledg.

Hung, C. Y., C. P. C. Albert, dan H. C. M. Eddie. 2002. Capital structure and profitability of the property and construction sectors in Hong Kong. Journal of Property Investment \& Finance 20 (2): 434-453.

Ikatan Akuntan Indonesia. 2009. Standar akuntansi keuangan entitas tanpa akuntabilitas publik. Jakarta: Dewan Standar Akuntansi Keuangan.

Jensen, M. C. 1986. Agency costs of free cash flow, corporate finance, and takeovers. The American Economic Review 76 (2): 323-329.

Jensen, M. C., dan W. H. Meckling. 1976. Theory of the firm: managerial behavior, agency costs and ownership structure. Journal of Financial Economics 3 (4): 305-360.

Kock, N. 2014. Advanced mediating effects tests, multi-group analyses, and measurement model assessments in PLS-based SEM. International Journal of e-Collaboration (IJeC) 10 (1): 1-13.

Kyereboah-Coleman, A. 2007a. The determinants of capital strucutue of microfinance institution in Ghana. SAJEMS 10 (2): 270-279. 
Kyereboah-Coleman, A. 2007b. The impact of capital structure on the performance of microfinance institutions. The Journal of Risk Finance 8 (1): 56-71. doi: 10.1108/15265940710721082.

Ledgerwood, J. 2008. Microfinance handbook: an institutinal and financial perspective-sustainable banking with the poor. Washington, D.C.: The World Bank.

Ledgerwood, J. 2013. The new microfinance handbook: a financial market system perspective. Washington, D.C.: The World Bank.

Lynch, L. J. 2003. The effect of medicare capital prospective payment regulation: additional evidence from hospital financing decisions. Journal of Accounting and Public Policy 22 (2): 151-173.

Margaritis, D., dan M. Psillaki. 2007. Capital structure and firm efficiency. Journal of Business Finance \& Accounting 34 (9-10): 1447-1469.

Meyer, R. L. 2001. Capital structure. The Journal of Economic Perspectives 15 (2): 81-102.

Modigliani, F., dan M. H. Miller. 1958. The cost of capital, corporation finance and the theory of investment. The American economic review 48 (3): 261-297.

Morduch, J. 2000. The microfinance schism. World Development 28 (4): 617-629.

Myers, S. C. 1977. The determinants of corporate borrowing. Journal of Financial Economics 5 (2): 147-175. . 1984. The capital structure puzzle. Journal of Finance 39 (3): 575-592.

Otero, M., dan E. Rhyne. 1994. The new word of microenterprise finance; building healthy financial institutions for the poor. United States of America: Kumarian Press.

Paxton, J., dan C. Fruman. 1997. Sustainable banking with the poor, outreach and sustainability: a comperative analysis of saving-first vs. credit-first. Washington D C.: The World Bank.

Robinson, M. S. 2001. The microfinance revolution: sustainable finance for the poor. Vol. 1: Washington D. C.: The World Bank. 2002. The microfinance revolution: lessons from Indonesia. Vol. 2. Washington D. C.: The World Bank.

Salim, M., dan R. Yadav. 2012. Capital structure and firm performance: evidence from Malaysian listed companies. Procedia - Social and Behavioral Sciences 65: 156-166.

Saltaji, I. M. F. 2013. Corporate governance and agency theory how to control agency costs. Internal Auditing \& Risk Management 4 (32): 47-60.

Sekabira, H. 2013. Capital structure and its role on performance of microfinance institutions: the Ugandan case. Sustainable Agriculture Research 2 (3): 86-100.

Sholihin, M., dan D. Ratmono. 2013. Analisis SEM-PLS dengan WarpPLS 3.0 untuk hubungan nonlinier dalam penelitian sosial dan bisnis. Yogyakarta: Andi Offset.

Titman, S., dan R. Wessels. 1988. The determinants of capital structure choice. The Journal of Finance 43 (1):1-19.

Torre, M. L., dan G. A. Vento. 2006. Microfinance. Edited by Philip Molyneux. British Library: Palgrave Macmillan Studies in Banking and Financial Institutions.

Umar, M., Z. Tanveer, S. Aslam, dan M. Sajid. 2012. Impact of capital structure on firms' financial performance: evidence from Pakistan. Research Journal of Finance and Accounting 3 (9): 1-12.

Uremadu, S. O. 2012. Bank capital structure, liquidity and profitability evidence from the Nigerian banking system. International Journal of Academic Research in Accounting Finance and Management Sciences 2 (1): 98113.

Weston, J. F., dan E. F. Brigham. 1990. Essentials of managerial finance. 9th ed. Hinsdale, IL: The Dryden Press.

Williams, J. 1987. Perquisites, risk, and capital structure. The Journal of Finance 42 (1): 29-48.

Wu, F., Z. Guan, dan R. Myers. 2014. Farm capital structure choice: theory and an empirical test. Agricultural Finance Review 74 (1): 115-132. 


\section{LAMPIRAN 1}

\begin{tabular}{|c|c|c|c|c|c|c|c|c|c|c|c|}
\hline Hibah & Ekuitas & Laba & Tab & FSS & Dep & \multicolumn{2}{|c|}{ Lingk Sub } & Quasi & Type as & $P$ value & VIF \\
\hline GRA & 1.000 & 0.000 & 0.000 & 0.000 & 0.000 & 0.000 & 0.000 & 0.000 & 0.000 & Formati & 0.029 \\
\hline$<0.001$ & 0.000 & 1 & 1.000 & & & & & & & & \\
\hline $\begin{array}{l}\text { EqRA } \\
\quad<0.001\end{array}$ & $\begin{array}{l}0.000 \\
0.000\end{array}$ & $\begin{array}{l}1.000 \\
1\end{array}$ & $\begin{array}{l}0.000 \\
1.000\end{array}$ & 0.000 & 0.000 & 0.000 & 0.000 & 0.000 & 0.000 & Formati & 0.029 \\
\hline $\begin{array}{l}\text { EaRA } \\
\quad<0.001\end{array}$ & $\begin{array}{l}0.000 \\
0.000\end{array}$ & $\begin{array}{l}0.000 \\
1\end{array}$ & $\begin{array}{l}1.000 \\
1.000\end{array}$ & 0.000 & 0.000 & 0.000 & 0.000 & 0.000 & 0.000 & Formati & 0.029 \\
\hline $\begin{array}{l}\text { SRA } \\
\quad<0.001\end{array}$ & $\begin{array}{l}0.000 \\
0.000\end{array}$ & $\begin{array}{l}0.000 \\
1\end{array}$ & $\begin{array}{l}0.000 \\
1.000\end{array}$ & 1.000 & 0.000 & 0.000 & 0.000 & 0.000 & 0.000 & Formati & 0.029 \\
\hline $\begin{array}{l}\text { FSS } \\
\quad<0.001\end{array}$ & $\begin{array}{l}0.000 \\
0.000\end{array}$ & $\begin{array}{l}0.000 \\
1\end{array}$ & $\begin{array}{l}0.000 \\
1.000\end{array}$ & 0.000 & 1.000 & 0.000 & 0.000 & 0.000 & 0.000 & Formati & 0.029 \\
\hline $\begin{array}{l}\text { DRA } \\
\quad<0.001\end{array}$ & $\begin{array}{l}0.000 \\
0.000\end{array}$ & $\begin{array}{l}0.000 \\
1\end{array}$ & $\begin{array}{l}0.000 \\
1.000\end{array}$ & 0.000 & 0.000 & 1.000 & 0.000 & 0.000 & 0.000 & Formati & 0.029 \\
\hline $\begin{array}{l}\text { LRA } \\
\quad<0.001\end{array}$ & $\begin{array}{l}0.000 \\
0.000\end{array}$ & $\begin{array}{l}0.000 \\
1\end{array}$ & $\begin{array}{l}0.000 \\
1.000\end{array}$ & 0.000 & 0.000 & 0.000 & 1.000 & 0.000 & 0.000 & Formati & 0.029 \\
\hline $\begin{array}{l}\text { SubRA } \\
\quad<0.001\end{array}$ & $\begin{array}{l}0.000 \\
0.000\end{array}$ & $\begin{array}{l}0.000 \\
1\end{array}$ & $\begin{array}{l}0.000 \\
1.000\end{array}$ & 0.000 & 0.000 & 0.000 & 0.000 & 1.000 & 0.000 & Formati & 0.029 \\
\hline $\begin{array}{l}\text { QRA } \\
\quad<0.001\end{array}$ & $\begin{array}{l}0.000 \\
0.000\end{array}$ & $\begin{array}{l}0.000 \\
1\end{array}$ & $\begin{array}{l}0.000 \\
1.000\end{array}$ & 0.000 & 0.000 & 0.000 & 0.000 & 0.000 & 1.000 & Formati & 0.029 \\
\hline
\end{tabular}

Notes: $\mathrm{P}$ values $<0.05$ dan VIFs $<2.5$ are desirable for formative indicators; VIF = indicator variance inflation factor; WLS = indicator weight-loading sign $(-1=$ Simpson's paradox in l.v.); ES = indicator effect size. 